\title{
Interview with Emil Volek and Andrés Pérez-Simón, translators of Zich's 'The Theatrical Illusion'
}

\section{Tomáš Kačer}

Emil Volek, Professor of Latin American Culture at Arizona State University, Tempe, received the 2016 Commemorative Centennial Medal 'José Lezama Lima' from the Instituto Cubano del Libro for the transmission of Slavic cultural theory to Spanishspeaking countries. His publications include Latin America Writes Back: Postmodernity in the Periphery (Routledge, 2002) and La mujer que quiso ser amada por Dios: Sor Juana Inés en la cruz de la crítica (Verbum, 2016).

Andrés Pérez-Simón, Associate Professor of Spanish Literature at the University of Cincinnati, is the author of Baroque Lorca: An Archaist Playwright for the New Stage (Routledge, 2019), Drama, literatura, filosofia: Itinerarios del realismo y el modernismo europeos (Editorial Fundamentos, 2015), as well as the editor and translator of Despistemes: La teoría literaria y cultural de Emil Volek (antología de textos) (Verbum, 2018).

Tomáš Kačer, a co-editor of the current issue, asked Professor Volek and Doctor PérezSimón about their experience with translating Zich as well as the reception and use of Zich's work outside the Czech Republic.

The interviewees responded in writing to questions sent by email to each writer by Tomáš Kačer. The questions and the answers were in English. The correspondence was finalized on 10 January 2020.

[TK] You have recently (PMLA 134.2, 2019) published a translation of Otakar Zich's 'The Theatrical Illusion', a part of the ninth chapter of The Aesthetics of Dramatic Art (Estetika dramatického umění), together with an introduction, which explains the context of the chapter's origin as well as a potential new reading of the text today. What made you choose this particular section as a representative example of Zich's ideas for the cutting-edge, methodology-savvy readers of PMLA's section 'Criticism in Translation'?

[EV] The passage on 'The Theatrical Illusion' stands out as a self-contained exploration that illustrates Zich's method of unfolding analysis, which proceeds by circling its topic and peeling off concentric coats of accumulated ballast to offer a complex, multifarious spatial-like 'x-ray' picture of the problem examined. He even leaves a margin of 'play' for further 'supplements (which is what the non-reductive complex vision does). 
If we take Estetika dramatického uměni from 1931, we have one 'look' under the heading 'Divadelní iluse' [The Theatrical Illusion] (ZICH 1931: 361-366), followed by another under the heading 'Rozbor divadelního zaměření' [Analysis of Theatrical Orientation] (ZICH 1931: 366-369), to come up with yet another striking 'take' on 'theatrical reality' on p. 372: 'Although parallel and responding to the life reality, the 'theatrical' reality is noetically different from and heterologous to it'.

One of the reasons traditionally oriented readers misunderstand Zich is the baffling fact that he does not go the traditional logical way of abstraction and elimination of non-essential 'details' to get to a one-point reductionist 'definition'. Another reason is the 'keying' factor: if the reader misses the clue given in passing in the 'Preface' ('I have worked out the problem of the theatrical illusion on the psychological, actually noetic, basis and from there I have tackled other questions,' ZICH 1931: 10), he misses the whole point of the book. The apparent 'psychology' is not oriented there towards 'fleeting psychic states of mind' but to objective, functional, definable and reproducible 'meanings'. It is all functional analysis and semantics except in name.

Zich's is not the only way of dealing with complex realities. Another is proposed in my Metaestructuralismo (1985), based on Mukařovský's complex and dynamic concept of 'structure' (still burdened by identity and determinism), but flexibilized by the puzzle of Ludwig Wittgenstein's 'family relations' (i.e. the changing 'identity' of elements into a play of compensations and substitutions within the structural equilibrium) and by René Thom's unraveling of the determinism/indeterminism dichotomy through his concept of 'catastrophes' (thus putting in question modern and postmodern epistemes, based on those extremes). Without my realizing it at the time, Thom introduced into my thinking the first glimpse of what would later be called 'chaos theory'. (The key introductory chapter of Metaestructuralismo has been long translated into Czech, but still awaits publication.) Maybe it was this background that opened my eyes when Jarmila Jandová and I were struggling over the translation of parts of his Estetika for a Spanish collection on Prague theatre theory (Teoria teatral de la Esuela de Praga: de la fenomenología a la semiótica performativa, 2013).

As can be seen in the 'Preface', Zich himself highlights theatrical illusion as the showpiece of his work. But beyond theatre, what he has to say there is equally valid for 'fiction' or for 'fictional worlds': these are not lies and unrealities, but realities in their own right, 'although parallel and responding to the life reality, ... [yet] noetically different from and heterologous to it'. This rich interdisciplinary texture calls out to be recognized for its potential.

[APS] I remember myself back in June of 2011 landing in Brno to participate in the 'Prague Semiotic Stage Revisited' conference held at Masaryk University. I was carrying with me a copy of Staging Philosophy (2006), a collection of fifteen essays exploring connections between the disciplines of philosophy and theatre/performance studies. David Z. Saltz, co-editor of the book, also authored an essay in which he questions what he regards as a dogma of twentieth century theatre criticism, namely the idea that 'theatrical performance presents illusory, as opposed to real, events'. To challenge 
this conceptualization, Saltz situates himself in dialogue with what he defined as a set of 'neo-Wittgensteinian theories of representation' (Gombrich, Aldrich, Wolheim, Walton) inspired in the final section of Ludwig Wittgenstein's Philosophical Investigations. Saltz refers to the phenomenon of 'seeing-as' (i.e. an image can be interpreted thing or another, without one of them necessarily being 'false') as one that can radically alter traditional semiotic theories of theatrical representation. Saltz considers the Prague Structuralists as typical representatives of the old paradigm, but my own experience discussing the theory and practice of the Prague School writings on theatre - I am thinking of Mukařovský and Veltruský in particular - lead me to sustain a view opposite to his, but it was not until I discovered Zich's Aesthetics of Dramatic Art that I realized I finally had the tools to counter this received discourse. When Emil proposed to work on the fragment 'The Theatrical Illusion', I saw it as an opportunity to claim the importance of Zich's phenomenological analysis of the theatrical event beyond an exclusionary, binary logic. (As we explain in the introduction to our translation, Zich conceptualizes theatrical fiction as 'another' reality, one that is not to be considered as 'false'.) In the introduction we explicitly connect Zich with Wittgenstein's non-dualistic approach to representation, thus proposing a new date for the tradition that Saltz invokes (Zich's Aesthetics of Dramatic Art came out in 1931, two decades before Wittgenstein's Philosophical Investigations).

[TK] Is a phenomenological reading of Zich's Aesthetics the factor which makes Zich's contribution to theatre theory and analysis topical even today? Which other factors are there that remain be explored and presented to an English-speaking readership?

[EV] Relating Zich to the early wave of phenomenological study of the arts is just the 'icing on the cake'. As important as historical justice and restitution is, it would mean little without having something substantive to offer to today's readers. However, as I have pointed out, Zich's text does not speak clearly for itself even for the Czech readers. This puts an even bigger burden on the translation and on the meta-critical apparatus to explain idiosyncrasies and point out what's alive there.

[APS] As Emil has explained, we need to get rid of the idea of Zich as a pre-semiotic aesthetician, a kind of unsophisticated precursor of the Prague School. In this regard, we should keep in mind the difference between Mukařovský, who in his 1933 review of Zich's Aesthetics made an effort to relate him to the Prague School, and Bogatyrev and Veltruský, younger scholars who were theoretically hostile towards Zich and more prone to produce a distorted image of his work. Once we move past this obstacle, I believe that Zich's theory of theatre will only be of interest to English-speaking scholars if presented in the way we do it with 'The Theatrical Illusion,' i.e. by presenting a selected excerpt of Zich's Aesthetics and have it not only translated but also accompanied by an introduction and annotations. I am skeptical about a complete translation of Zich's treatise having a full impact on international scholars who are not familiar with the context of his work, nor with the Prague School writings that came immediately after his Aesthetics. I suggest starting by identifying certain passages of Zich's treatise, in 
particular those that explore the 'live' aspects of theatrical performance. (This brings us to phenomenology, which was part of your question, of course.) Zich should be recognized as one of the fathers of the discipline of the theatre studies in Europe, as he considered performance, rather than the dramatic text, as object of study.

[TK] Concepts such as 'illusion' and 'reality', which are crucial in the section, have undergone a tumultuous development over the last one hundred years in theatre theory and practice. What difficulties in today's reception of Zich can you foresee?

[EV] Many. Precisely because these concepts are at the intersection of infinite number of perspectives. In 'The Theatrical Illusion,' if the reader is not extremely focused, in some passages he may easily lose the thread of the different 'realities' referred to. In our translation we have tried to guide the reader through the occasional maze.

[APS] The main problem I see is that a number of contemporary theatre theorists refuse to operate with the notion of fiction, not even with a broad idea of it. There is so much recent scholarship that focuses on bodies and movements without considering that the actors' physical presence is presented to us 'bracketed', so to speak, by fiction. This is a deficit of the so-called 'post-dramatic' paradigm, and it makes the task of divulging Zich even harder.

[TK] As scholars working also in Spanish-speaking contexts, can you guess which aspects of Zich's 'Theatrical Illusion' will be approached differently by readers from English- and Spanishspeaking backgrounds, and why?

[EV] I guess that the technical semantic analysis found in Zich will appeal more to Spanish and Spanish-American theater theorists than to the Anglo-Americans, who are today more ideologically and gender oriented. But both will struggle with Zich's phenomenological method of analysis because of their traditional 'logocentric' biases: to unlearn the Cartesian way of building the complex from the apparent simple, and not the other way around, will be a struggle everywhere.

[APS] A couple of years ago, a veteran theatre scholar from Germany told me she was envious of the robust tradition of theatre semiotics in Spain and Italy, a corpus of texts that she could only partially access through English translations of a few Spanish and Italian works mostly published in the 1980s. So it is safe to assume that scholars and theatre practitioners in Spain and Latin America will interpret Zich in line with a tradition of theatre semiotics that has not been completely been replaced. The tricky part is that while Spanish-speaking scholars may be considered a more 'friendly' audience to Zich, there is the risk of them reducing Zich's theoretical apparatus to what Volek has elsewhere referred to as 'the straightjacket of 'semiologization'. So let's not take anything for granted. This situation, of course, is different in the theatre departments of Anglo-American universities, which expelled theatre semiotics from the classrooms as early as the 1990s (see the gloomy tone of "Post'-Script: Post-Semiotics, Posthumous Semiotics, Closet Drama,' the text Keir Elam wrote for the 2002 edition of his The 
Semiotics of Theatre and Drama, originally released in 1980). Accepting the fact that there are very few self-identified semioticians with potential interest in a 1931 book by a relatively unknown Czech theatre and opera scholar, I believe we can still reach a good number of readers in the English-speaking world by presenting Zich as someone who pioneered an interdisciplinary approach to the theatrical event.

[TK] What are the (dis)advantages of a translator's job from Czech into English carried out in tandem, where one of you is a native speaker of Czech and the other is not?

[EV] Every translation is a big learning opportunity: as a starting point, one cannot just 'read,' because one has to stop and turn over every word and every phrase. Each language makes you re-think the most current expressions. It was a blessing working with Andrés, because we could put to good use our accumulated experience in some twenty years of on and off intellectual collaboration in three languages. Before this, we had a previous great experience with his translation into Spanish from English of Jiři Veltruskýs overview of the Prague School theatre studies (published in journal Gestos in 2011); I helped then from the putative Czech side (since the Czech 'original' was also a translation). The Zich translation was a piece of cake. The zillion versions we exchanged are a testament to the ease. This could not have been done in this way twenty years ago... The last struggle was not with Andrés but with the single-minded corrector of PMLA, who tried to undo whatever fine point we attempted to make and turn it into a banality. I hope we have still managed to save something from this massacre.

[APS] Borrowing from Viktor Shklovsky, I would define our translation as an exercise of linguistic estrangement. We did not establish a clear trajectory from text 'a' to text 'b'; instead, we proceeded by approaching Zich's work from different angles. Once we agreed on taking up this project, I obtained funding from the University of Cincinnati to bring Emil from Arizona to Cincinnati to work with me on the first draft of the translation back in March of 2016. I knew the Spanish version of Zich's 'The Theatrical Illusion' that Jarmila Jandová and Emil Volek had printed three years earlier, and once in Cincinnati, Emil provided me with the original text in Czech with some annotations in English. I drafted the first English version, and from then on we were engaged in an exchange of emails that lasted for months before we felt confident that the text was suitable for a general English-speaking audience with no necessary background in theatre studies. The PMLA board approved our proposal sometime in late 2017, and it was then when the translation entered its third and last phase. Every line in our introduction and translation was then scrutinized by a senior editor of MLA publications. There was a back-and-forth dialogue that involved us accepting stylistic suggestions from him, while also standing firm in defence of certain semantic decisions, as Emil just mentioned. February 2019 was the date of completion of the final versions of the introduction and translation of 'The Theatrical Illusion,' after a journey of almost three years of work. 


\section{Bibliography}

ELAM, Keir. 2002. 'Post'-Script: Post-Semiotics, Posthumous Semiotics, Closet Drama. In Keir Elam. The Semiotics of Theatre and Drama. London/New York: Routledge, 2002: 191-219.

JANDOVÁ, Jarmila and Emil VOLEK (eds. and trans.). 2013. Teoría teatral de la Escuela de Praga: de la fenomenología a la semiótica performativa. Madrid-Bogotá: Fundamentos/RESAD-Universidad Nacional de Colombia, 2013.

KRASNER, David and David Z. SALTZ (eds.). 2006. Staging Philosophy: Intersections of Theater, Performance, and Philosophy. Ann Arbor: University of Michigan Press, 2006.

PÉREZ-SIMÓN, Andrés. 2011. Introducción a ,La teoría teatral de la Escuela de Praga“ de Jiri Veltrusky. GESTOS: Revista de teoría y práctica del teatro hispanicos 26 (51): 2011: 15-34.

VOLEK, Emil. 1985. Metaestructuralismo: poética moderna, semiótica narrativa y filosofía de las ciencias sociales. Madrid: FUNDAMENTOS EDITORIAL, 1985.

ZICH, Otakar. 1931. Estetika dramatického umění [The Aesthetics of Dramatic Art]. $1^{\text {st }}$ ed. Prague: Melantrich, 1931.

ZICH, Otakar. 2019. The Theatrical Illusion. Intr. and transl. by Emil Volek and Andrés Pérez-Simón. PMLA 134(2): 2019: 351-358. Avalaible online at: https://doi.org/10.1632/ pmla.2019.134.2.351 